\title{
Downregulation of $\mathrm{FOXP3}$ in neutrophils by IL-8 promotes the progression of oral squamous cell carcinoma
}

\author{
CHUANGUI ZENG ${ }^{1,2^{*}}$, HAI KUANG ${ }^{1 *}$, WAN FAN $^{1}$, XUERU CHEN $^{1}$, TAO YU $^{1}$, \\ QINCHAO TANG ${ }^{1}$, ZHUOQIAN ZHOU $^{1}$ and FEIXIN LIANG ${ }^{1}$ \\ ${ }^{1}$ Department of Oral and Maxillofacial Surgery, College of Stomatology, Guangxi Medical University, Nanning, \\ Guangxi 530021; ${ }^{2}$ Department of Stomatology, The First People's Hospital of Huaihua, Huaihua, Hunan 418000, P.R. China
}

Received February 21, 2019; Accepted July 3, 2019

DOI: $10.3892 / 01.2019 .10828$

\begin{abstract}
The aim of the present study was to investigate the effects of the transcription factor forkhead box P3 (FOXP3) in neutrophils on the progression of oral squamous cell carcinoma (OSCC). Cancer tissue samples and paracarcinoma tissues were collected from 23 patients with OSCC for the current study. In addition, SCC-9, a human tongue carcinoma cell line, was co-cultured with primary human neutrophils and treated with recombinant interleukin 8 (IL-8). The effect of FOXP3 on the proliferation of SCC-9 cells was analyzed using a Cell Counting Kit 8 assay. FOXP3 expression in neutrophils was analyzed by quantitative PCR following IL- 8 treatment. FOXP3 protein expression in neutrophils and the amount of IL-8 protein in the OSCC tumor microenvironment were determined by immunofluorescence analysis. The present study demonstrated that IL-8 downregulated FOXP3 mRNA expression in neutrophils. Neutrophils and peptide P60, a specific inhibitor of $F O X P 3$, increased proliferation of SCC-9 cells. In patients with OSCC, FOXP3 protein expression in neutrophils of the stage IV group was significantly lower compared with that of the stage II and stage III groups, while IL-8 protein expression was higher in cancer tissues compared with that in paracarcinoma tissues. In summary, IL-8 in the tumor microenvironment may recruit neutrophils, and downregulation of $F O X P 3$ in neutrophils by $\mathrm{IL}-8$ may promote the progression of OSCC.
\end{abstract}

Correspondence to: Dr Feixin Liang, Department of Oral and Maxillofacial Surgery, College of Stomatology, Guangxi Medical University, 10-2 ShuangYong Road, Nanning, Guangxi 530021, P.R. China

E-mail: liangfx@hotmail.com

${ }^{*}$ Contributed equally

Key words: forkhead box P3, interleukin 8, neutrophils, oral squamous cell carcinoma, proliferation

\section{Introduction}

In 2012, 300,400 newly diagnosed cases of oral cancer were reported, and 145,400 patients succumbed to oral cancer worldwide (1). Oral squamous cell carcinomas (OSCCs) are the most common type of oral cancer (2). Interleukin (IL)-8 is a key cytokine that promotes tumor progression (3). Additionally, a previous study demonstrated that OSCC cells may secrete IL-8 (4). IL-8 released by tumor cells recruits neutrophils from the circulating blood to the local tumor microenvironment (3). Neutrophils entering the tumor microenvironment exert various biological functions, including promotion of tumor angiogenesis and tumor cell proliferation $(5,6)$.

The forkhead/winglike spiral transcription factor forkhead box P3 (FOXP3) is a member of the forkhead transcription factor family (7). As a key transcription factor, FOXP3 serves an important role in the formation of regulatory $\mathrm{T}$ cells (Tregs) and their immunosuppressive function (7). Several studies on FOXP3 have focused on Tregs (8-10), and previous studies demonstrated that FOXP3 is expressed not only in Tregs, but also in various types of cancer (11-13), including pancreatic cancer (11). A study by Hinz et al (11) indicated that pancreatic cancer cells expressing FOXP3 attenuate activated T-cell proliferation. By specifically reducing FOXP3 expression in pancreatic cancer cells, its inhibitory effect on T-cell proliferation can be partially reduced (11).

Neutrophil infiltration of a tumor microenvironment is a common manifestation of tumor pathology $(5,6,14,15)$. Tumor-associated neutrophils (TANs) are classified as the N1 type, with an antitumor effect, and the N2 type, with a tumor-promoting effect $(16,17)$. The phenotype of TANs is associated with factors in the tumor microenvironment, including transforming growth factor $\beta$ and interferon $\beta(16,17)$. A study by Nozawa et al (18) revealed that TANs promote tumor cell proliferation in pancreatic cancer. Additionally, neutrophils are not only common immune killer cells, but also a potential immunoregulatory cell type (19). Whether FOXP3 is expressed in neutrophils and whether its expression serves a role in tumor progression, to the best of our knowledge, has not been reported on so far.

In the present study, quantitative PCR (qPCR) was performed to detect the effect of cytokine IL- 8 on the expression levels of FOXP3 in neutrophils, and a Cell Counting Kit 8 
(CCK-8) proliferation assay was used to evaluate the effect of FOXP3 expression on the proliferation of OSCC cells in vitro. Furthermore, immunofluorescence staining was conducted to detect the expression levels of FOXP3 in neutrophils in OSCC tissue samples in vivo. The present study broadens the range of known mechanisms via which neutrophils promote tumor cell proliferation and tumor progression.

\section{Materials and methods}

Human samples. Cancer tissue samples and paracarcinoma tissues $(1.5 \mathrm{~cm}$ away from the cancer) were collected from patients with OSCC at the College of Stomatology, Guangxi Medical University (Nanning, China) between July 2017 and December 2017. Patients with OSCC included in the present study had not been previously treated, and were candidates for surgical resection of primary tumors and selective or radical neck dissection. The exclusion criteria were: i) Patients with other severe systemic disorders or distant metastasis; and ii) patients with samples that were inadequate for immunofluorescence staining.

Samples from 23 patients with OSCC were included in the present study. The median age of the patients was 52 years (range, 24-82 years); 14 patients were male, and 9 patients were female. According to the Union for International Cancer Control 7th Edition staging system (20), the patients were divided into stage II $(n=6)$, III $(n=7)$ and IV $(n=10)$ groups. Each sample was stained using hematoxylin and eosin as described previously (21). Histopathological diagnoses were confirmed by at least two independent pathologists. Notable intercellular bridging and keratinized beads were observed in the cancer tissues, histological features which are consistent with squamous cell carcinoma. Tissue samples were soaked in $10 \%$ buffered formalin at room temperature for $48 \mathrm{~h}$, followed by paraffin embedding. Blood samples were obtained from 9 healthy donors $(5$ men and 4 women; median age, 45; age range, 28-56) and placed into heparinized tubes at room temperature and processed within $2 \mathrm{~h}$ of blood collection. The Ethics Committee of Guangxi Medical University approved the study protocol, and all patients and healthy donors provided written informed consent.

Cells and cell culture. SCC-9 cells were obtained from the Fuheng Cell Center (Shanghai, China). The cell line was authenticated by Shanghai Biowing Applied Biotechnology Co., Ltd., using short tandem repeat (STR) profiling (22), according to the American National Standards Institute Standard (ASN-0002) set forth by the American Type Culture Collection Standards Development Organization (22). The STR results revealed that this cell line had no multiple alleles and no cross contamination of human cells. The DNA of the cell line was found to match perfectly with the type of cells in a cell line retrieval, and the DSMZ database (dsmz. de/services/human-and-animal-cell-lines/online-str-analysis) demonstrated that the cells, called SCC-9, corresponded to the cell number CRL-1629. SCC-9 cells were maintained in DMEM/F12 medium (cat. no. 319-085-CL; Wisent Biotechnology) supplemented with 10\% FBS (cat. no. 086-110; Wisent Biotechnology) and 1\% penicillin/streptomycin solution (cat. no. 450-201-EL; Wisent Biotechnology). Neutrophils were isolated from healthy donor blood samples by means of Polymorphprep ${ }^{\mathrm{TM}}$ (cat. no. 1114683; Axis-Shield Diagnostics, Ltd.) according to the manufacturer's protocol, and neutrophils were resuspended in RPMI-1640 medium (cat. no. 350-006-CL; Wisent Biotechnology) supplemented with $10 \%$ FBS and $1 \%$ penicillin/streptomycin solution. All cells were cultured at $37^{\circ} \mathrm{C}$ in a humidified atmosphere containing $5 \% \mathrm{CO}_{2}$, and all subsequent culturing were performed under the same conditions.

Isolation of neutrophils and co-culture with SCC-9 cells. To isolate neutrophils, heparinized blood was layered on Polymorphprep according to the manufacturer's protocol. Briefly, $5 \mathrm{ml}$ heparinized blood was carefully layered over $5 \mathrm{ml}$ Polymorphprep in a $15 \mathrm{ml}$ centrifuge tube. The samples were centrifuged at $500 \mathrm{x} \mathrm{g}$ for $30 \mathrm{~min}$ at $20^{\circ} \mathrm{C}$. Subsequently, the lower phase containing neutrophils was collected, diluted with PBS (cat. no. P1010; Beijing Solarbio Science \& Technology Co., Ltd.) and centrifuged at $400 \mathrm{x} \mathrm{g}$ for $10 \mathrm{~min}$ at $20^{\circ} \mathrm{C}$. The neutrophils were resuspended in RPMI-1640 medium supplemented with $10 \%$ FBS.

The co-culture experiments were conducted in 96-well plates, as described previously (23). The SCC-9 cells were plated at a density of $5 \times 10^{5}$ cells/ml in DMEM/F12 medium containing $10 \%$ FBS. After $24 \mathrm{~h}$, the medium was discarded, and the cells were incubated in $100 \mu \mathrm{l}$ RPMI-1640 medium supplemented with $10 \%$ FBS. Neutrophils were directly added to the tumor cells at a final density of $5 \times 10^{5}$ cells $/ \mathrm{ml}$. To investigate the effect of FOXP3 on the proliferation of SCC-9 cells in co-culture, the cells were treated with IL-8 $(100 \mathrm{ng} / \mathrm{ml}$; cat. no. 200-08; PeproTech, Inc.) or peptide P60 (P60; $100 \mu \mathrm{M}$; cat. no. 350582; Abbiotec, Inc.), a specific peptide inhibitor of FOXP3 (24). The plates were incubated for $24 \mathrm{~h}$ at $37^{\circ} \mathrm{C}$ in a humidified atmosphere containing $5 \% \mathrm{CO}_{2}$.

Cell proliferation assay. Cell proliferation was assessed using the CCK-8 assay (cat.no. 70-CCK805; Hangzhou MultiSciences (Lianke) Biotech Co., Ltd.) according to the manufacturer's protocol. For co-culture experiments, SCC-9 cells were plated at a density of $5 \times 10^{5}$ cells/ml in DMEM/F12 medium containing $10 \% \mathrm{FBS}$. After $24 \mathrm{~h}$, the medium was discarded, and the cells were incubated in $100 \mu \mathrm{l}$ of RPMI-1640 medium supplemented with $10 \%$ FBS. Neutrophils were directly added to the tumor cells at a final density of $5 \times 10^{5}$ cells $/ \mathrm{ml}$. To investigate the effect of FOXP3 on the proliferation of SCC-9 cells in co-culture, the cells were treated with human recombinant IL-8 (100 ng/ml; cat. no. 200-08; PeproTech, Inc.) or P60. Subsequently, $100 \mu \mathrm{l}$ RPMI-1640 medium containing $10 \% \mathrm{FBS}$ and $10 \mu \mathrm{l} \mathrm{CCK}-8$ reagent was added. Optical density was measured at $450 \mathrm{~nm}$ on a microplate reader after $2 \mathrm{~h}$. The experiment was independently repeated three times.

Reverse-transcription $(R T)$ - $q P C R$. To examine the effects of IL-8 on FOXP3 expression in neutrophils, neutrophils $\left(1 \times 10^{6}\right.$ cells/well) were cultured in 24-well plates in RPMI-1640 medium supplemented with $10 \%$ FBS and treated with recombinant human IL-8 (100 ng/ml, diluted in distilled water) or treated with the same volume of PBS (control group) for $12 \mathrm{~h}$.

For mRNA analysis, RNA (200 ng per sample) was extracted from neutrophils using RNAiso Plus reagent (cat. no. 9108; Takara Bio, Inc.) according to the manufacturer's 
protocol. Complementary DNA (cDNA) was synthesized with the PrimeScript ${ }^{\text {TM }}$ RT Reagent kit with gDNA Eraser (Perfect Real Time) (cat. no. RR047A; Takara Bio, Inc.) according to the manufacturer's protocol. The reverse transcription temperature protocol used was: $37^{\circ} \mathrm{C}$ for $15 \mathrm{~min}$ followed by $85^{\circ} \mathrm{C}$ for $5 \mathrm{sec}$. The primers for $G A P D H$ and FOXP3 were purchased from Takara (Takara Bio, Inc.). The primer sequences were as follows: FOXP3 forward, 5'-GAA ACAGCACATTCCCAGAGTTC-3' and reverse, 5'-ATGGCC CAGCGGATGAG-3' (25); and GAPDH forward, 5'-GCA CCGTCA AGGCTGAGAAC-3' and reverse, 5'-TGGTGA AGACGCCAGTGGA-3'. GAPDH was used as an internal control. qPCR was performed on an ABI 7500 real-time PCR system (Applied Biosystems; Thermo Fisher Scientific, Inc.) using TB Premix Ex Taq ${ }^{\mathrm{TM}}$ II (cat. no. RR820A; Takara Bio, Inc.) according to the manufacturer's protocol. The thermocycling conditions were: Denaturation at $95^{\circ} \mathrm{C}$ for $30 \mathrm{sec}$; followed by 40 cycles at $95^{\circ} \mathrm{C}$ for $5 \mathrm{sec}$ and $60^{\circ} \mathrm{C}$ for $34 \mathrm{sec}$, and a final extension step of $95^{\circ} \mathrm{C}$ for $15 \mathrm{sec}, 60^{\circ} \mathrm{C}$ for $1 \mathrm{~min}$, $95^{\circ} \mathrm{C}$ for $15 \mathrm{sec}$ and $60^{\circ} \mathrm{C}$ for $15 \mathrm{sec}$. The experiment was independently repeated three times. The $2^{-\Delta \Delta \mathrm{Cq}}$ method was used to calculate the relative fold in gene expression determined from quantitative PCR experiments $(26,27)$. The fold change in cDNA of the target gene relative to the GAPDH endogenous control was determined by the following equation: Fold change $=2^{-\Delta \Delta \mathrm{Cq}}$, where $\Delta \Delta \mathrm{Cq}=\left[\left(\mathrm{Cq}_{\mathrm{FOXP} 3}-\mathrm{Cq}_{\mathrm{GAPDH}}\right)\right.$ (experimental group)- $\left(\mathrm{Cq}_{\mathrm{FOXP} 3}-\mathrm{Cq}_{\mathrm{GAPDH}}\right)$ (control group)]. The $\mathrm{Ct}$ value is the number of amplification cycles at which the fluorescence signal reaches a set threshold.

Immunofluorescence staining. Tissue samples were cut into $4-\mu$ m-thick sections. The sections were deparaffinized with xylene and rehydrated in a descending ethanol series of 70 , $80,90,95$ and $100 \%$, followed by antigen retrieval with citrate buffer (cat. no. mvs-0066; Fuzhou Maixin Biotech Co., Ltd.) with $\mathrm{pH}$ 6.0, microwaved on high power to boiling point for $3 \mathrm{~min}$ and subsequently blocked with 5\% BSA (Beijing Solarbio Science \& Technology Co., Ltd.; cat. no. SW3015) for $30 \mathrm{~min}$. The sections were incubated at $4^{\circ} \mathrm{C}$ overnight with the following primary antibodies at 1:100 dilution: Rabbit polyclonal anti-human FOXP3 antibody (cat. no. ab10901; Abcam), mouse monoclonal anti-human myeloperoxidase (MPO) antibody (cat. no. ab25989; Abcam) and mouse monoclonal anti-human IL-8 antibody (cat. no. sc-8427; Santa Cruz Biotechnology, Inc.). The sections were washed with PBS, followed by incubation with the following secondary antibodies at 1:1,000 dilution for $1 \mathrm{~h}$ at $37^{\circ} \mathrm{C}$ : Goat anti-rabbit immunoglobulin G (IgG) antibody (cat. no. ab150077; Abcam) and goat anti-mouse IgG antibody (cat. no. ab150114; Abcam). Sections were washed with PBS followed by incubation with DAPI (5 $\mu \mathrm{g} / \mathrm{ml}$; cat. no. C0060; Beijing Solarbio Science \& Technology Co., Ltd.) at $37^{\circ} \mathrm{C}$ for $10 \mathrm{~min}$. The tissue sections were washed with PBS before mounting on the slides with Solarbio Fluorescence Mounting medium (cat. no. S2100; Beijing Solarbio Science \& Technology Co., Ltd.). SCC-9 cells were fixed with $4 \%$ paraformaldehyde at room temperature, and permeabilized with $0.3 \%$ Triton X-100 (Beijing Solarbio Science \& Technology Co., Ltd.; cat. no. T8200) for $20 \mathrm{~min}$. After blocking with $5 \% \mathrm{BSA}$ at $37^{\circ} \mathrm{C}$ for $30 \mathrm{~min}$, the samples were stained as described above. Images were captured under a fluorescence microscope (magnification, x400; Olympus Corporation), and the integrated optical density (IOD) of FOXP3 protein expression in three randomly selected fields was measured using Image Pro-Plus 6.0 software (version 6.0; Media Cybernetics, Inc.). The IOD mean value of each section was determined after analyzing three random images.

Statistical analysis. Each experiment was repeated three times and the data are expressed as the mean \pm standard deviation. IBM SPSS Statistics software (version 20.0; IBM Corp.) was used to perform statistical analyses. A paired Student's t-test was used to analyze the difference between FOXP3 mRNA expression in neutrophils. An unpaired Student's t-test was used to analyze the immunofluorescence results of FOXP3 protein expression in neutrophils. Cell proliferation assays were analyzed using a one-way ANOVA with a post-hoc Tukey's. $\mathrm{P}<0.05$ was considered to indicate a statistically significant difference.

\section{Results}

Neutrophils and IL-8 promote SCC-9 cell proliferation. OSCC cells secrete IL-8, and high concentrations of IL-8 recruit neutrophils to the cancer microenvironment; thus, there are large quantities of IL-8 and neutrophils in the tumor microenvironment $(3,4)$. To investigate the effects of IL-8 and neutrophils on the proliferation of OSCC cells, neutrophils and OSCC cells were co-cultured and treated with IL- 8 for $24 \mathrm{~h}$, and SCC-9 cell proliferation was assessed using a CCK-8 assay. The results revealed that IL- 8 and neutrophils exerted a synergistic effect on SCC-9 cells and together promoted their proliferation $(\mathrm{P}<0.001$; Fig. 1).

It has previously been shown that neutrophils adhere to the surface of epithelial cells through adhesion molecules (28), and IL-8 promotes the adhesion of neutrophils by upregulating the expression of these adhesion molecules (29). To confirm that the increased proliferation in the SCC-9/neutrophil/IL-8 group was not due to increased adhesion promoted by neutrophils, after washing, neutrophils were detected by immunofluorescence staining using an MPO antibody, which has been used as a neutrophil-specific antibody in previous studies $(30,31)$. The results confirmed that there were no adherent neutrophils on the surface of SCC-9 cells in 96-well plates after washing (Fig. S1).

IL-8 downregulates FOXP3 mRNA expression in neutrophils. Various studies have demonstrated that FOXP3 is expressed in a variety of tumor cells and is involved in tumor cell proliferation and apoptosis $(11,12,32)$. To test if IL-8 induces a change in FOXP3 expression in neutrophils, human peripheral blood neutrophils were stimulated with recombinant human IL-8 and the mRNA expression levels of FOXP3 in neutrophils were evaluated. The results indicated that IL- 8 downregulated FOXP3 mRNA expression in neutrophils ( $\mathrm{P}=0.005$; Fig. 2$)$.

Neutrophils and an inhibitor of FOXP3 promote proliferation of SCC-9 cells. To investigate the effect of FOXP3 in neutrophils on the proliferation of SCC-9 cells, neutrophils and OSCC cells were co-cultured and treated with P60, a specific peptide inhibitor of FOXP3, for $24 \mathrm{~h}$. Subsequently, SCC-9 cell proliferation was assessed using a CCK-8 assay. The 


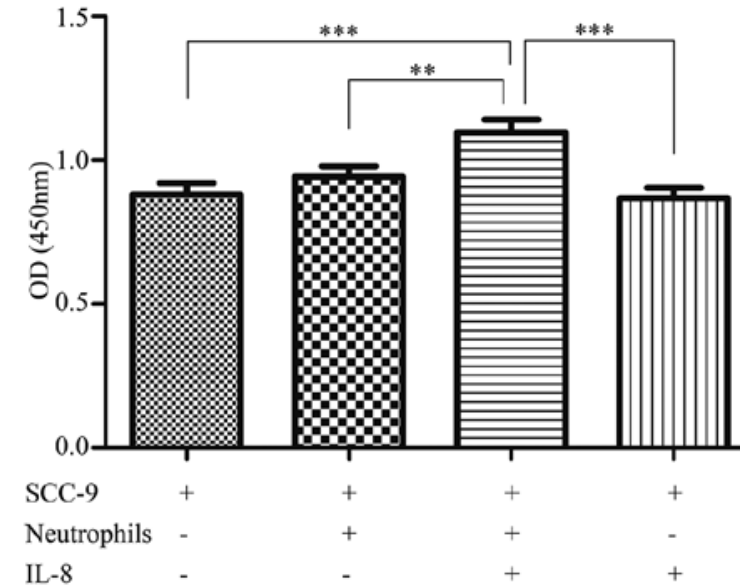

Figure 1. Neutrophils and IL-8 promote SCC-9 cell proliferation in vitro. SCC-9 cell were co-cultured with neutrophils and treated with IL-8 $(100 \mathrm{ng} / \mathrm{ml})$ for $24 \mathrm{~h}$. Neutrophils and IL-8 increased SCC-9 cell proliferation compared with SCC-9 cells alone. ${ }^{* *} \mathrm{P}<0.01,{ }^{* * * *} \mathrm{P}<0.001$. The experiment was independently repeated three times. Data are presented as the mean $\pm \mathrm{SD}$. ${ }^{* *} \mathrm{P}<0.01,{ }^{* * * *} \mathrm{P}<0.001$. IL-8, interleukin 8; OD, optical density.

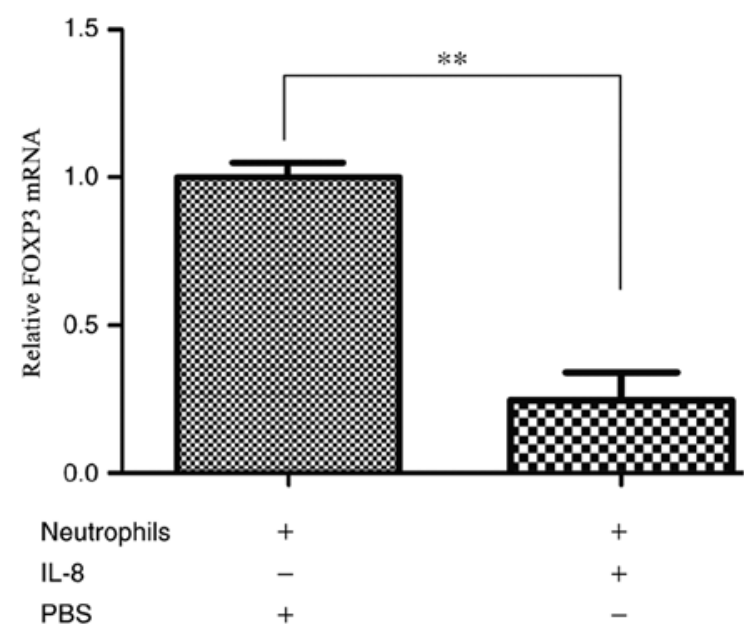

Figure 2. IL-8 downregulates FOXP3 expression in neutrophils. Neutrophils were treated with IL-8 $(100 \mathrm{ng} / \mathrm{ml})$ or PBS for 12 h. FOXP3 mRNA expression was detected by qPCR, and GAPDH served as an internal control. The experiment was independently repeated three times. Data are presented as the mean $\pm \mathrm{SD} .{ }^{* *} \mathrm{P}<0.01$. FOXP3, forkhead box P3; IL-8, interleukin 8 .

results revealed that $\mathrm{P} 60$ treatment of co-cultured neutrophils and SCC-9 cells increased the proliferation of SCC-9 cells in compared with SCC-9 cells alone ( $\mathrm{P}=0.004$; Fig. 3), suggesting that a combination of neutrophils and an inhibitor of FOXP3 together promote the proliferation of SCC-9 cells.

Protein expression levels of FOXP3 in neutrophils in the OSCC tumor microenvironment. To investigate the association of FOXP3 in neutrophils and OSCC in vivo, cancer tissue samples from 23 patients were stained by immunofluorescence to detect FOXP3 expression in neutrophils infiltrating the tumor microenvironment. MPO was also stained as marker of neutrophils $(30,31)$. The results revealed that FOXP3 protein expression in neutrophils was significantly lower in patients with stage IV cancer compared with those with stage II ( $\mathrm{P}=0.001)$ and III $(\mathrm{P}=0.008)$ (Fig. 4).

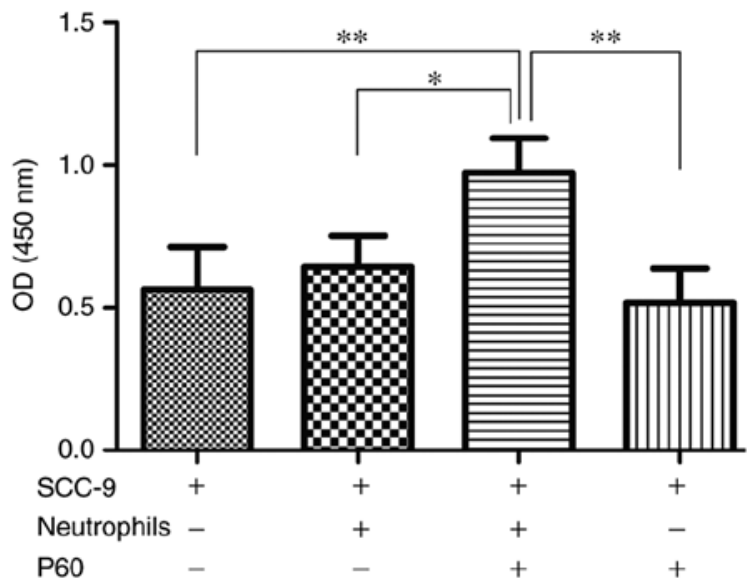

Figure 3. Neutrophils and inhibition of FOXP3 promote proliferation of SCC-9 cells. SCC-9 cells were co-cultured with neutrophils and treated with P60, an inhibitor of FOXP3 $(100 \mu \mathrm{M})$ for $24 \mathrm{~h}$. The experiment was independently repeated three times. Data are presented as the mean $\pm \mathrm{SD}$. ${ }^{*} \mathrm{P}<0.05$, ${ }^{* *} \mathrm{P}<0.01$. OD, optical density; FOXP3, forkhead box P3; P60, peptide P60.

Protein expression levels of $I L-8$ in the OSCC tumor microenvironment. Fujita et al (33) reported that high expression of IL-8 in oral cancer is associated with poor prognosis, suggesting that IL-8 may promote proliferation and metastasis of oral cancer cells. The aforementioned in vitro co-culture experimental results revealed that IL-8 downregulated FOXP3 mRNA expression in neutrophils, and neutrophils treated with inhibitor of FOXP3 enhanced proliferation of SCC-9 cells. To investigate if IL-8 protein expression is also altered in vivo, immunofluorescence was conducted to detect IL-8 protein expression in cancer and paracarcinoma tissue samples from patients with OSCC. The results demonstrated that IL-8 protein was expressed in both OSCC tissues and paracarcinoma tissues (Fig. 5).

\section{Discussion}

Recent studies (34-36) suggest that FOXP3 is expressed in a variety of tumor cells and its protumor or antitumor roles are a controversial topic. Hinz et al (11) demonstrated that T-cell proliferation is observed after specific silencing of FOXP3 expression with small interfering RNAs in pancreatic cancer cells. This result indicates that pancreatic cancer cells expressing FOXP3 inhibit T-cell proliferation, and thereby promote tumor progression. However, FOXP3 also performs a tumor suppressor function in breast cancer cells $(37,38)$. Zhang et al (37) reported that FOXP3 is expressed in breast cancer cells and is negatively associated with breast cancer metastasis. Furthermore, a previous study demonstrated that FOXP3 inhibits adhesion and invasiveness of breast cancer cells by downregulating CD44 (37). To date, however, FOXP3 expression and its role in neutrophils, to the best of our knowledge, have not been reported on. The present study demonstrated that IL-8 downregulated the expression of FOXP3 in neutrophils, and following P60 inhibition of FOXP3, neutrophils promoted the proliferation of SCC-9 cells. A study by Casares et al (24) reported that P60 enters the cells, downregulates $F O X P 3$ nuclear translocation and inhibits the function of FOXP3 protein in vitro. It has been identified that P60 alone 

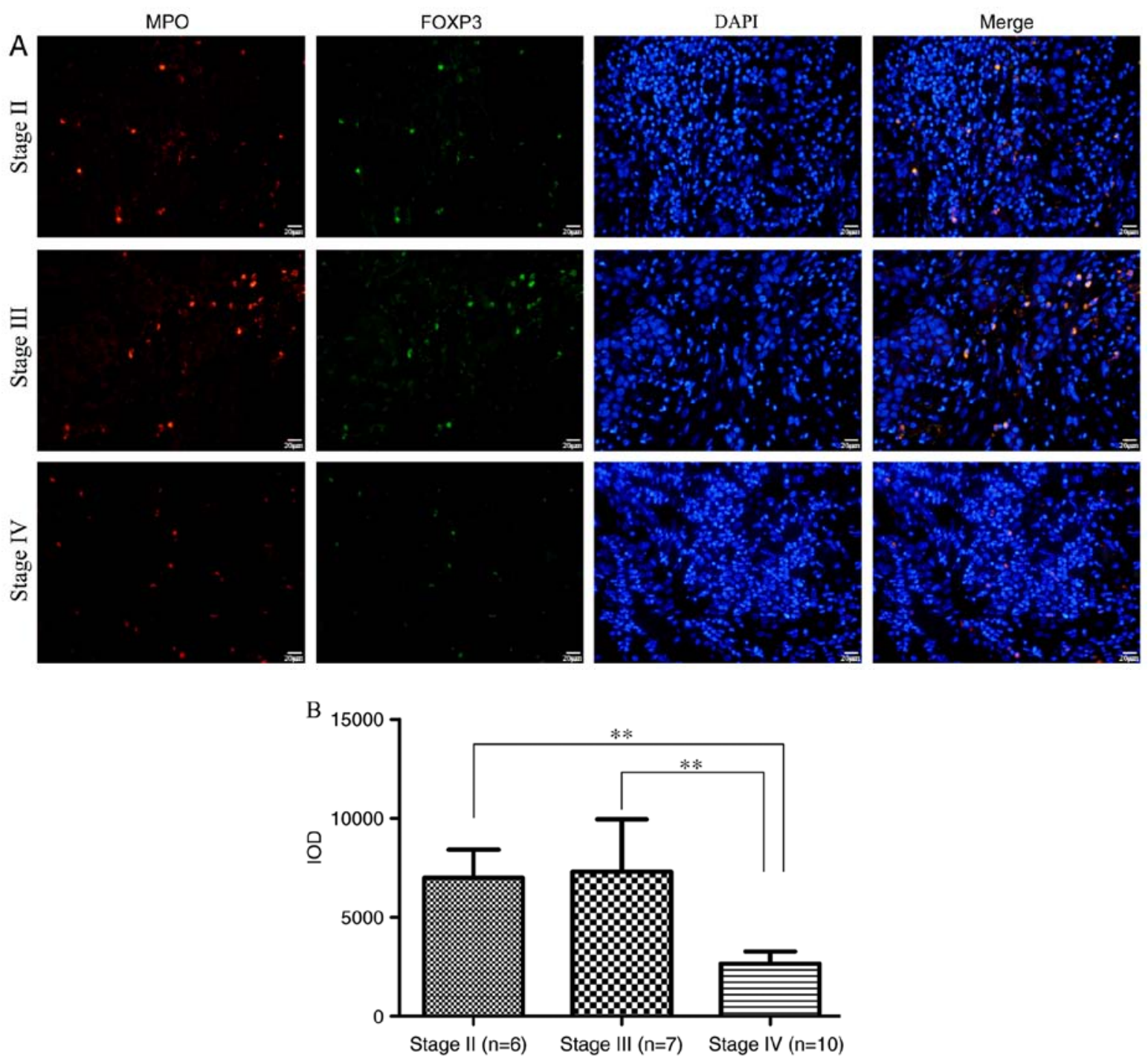

Figure 4. FOXP3 protein expression in neutrophils in the oral squamous cell carcinoma tumor microenvironment. (A) FOXP3 (green) and MPO (red) expression in 23 cancer tissue samples at stage II, III and IV was detected by immunofluorescence. Nuclei (blue) were counterstained with DAPI. Scale bar, $20 \mu \mathrm{m}$. (B) FOXP3 expression was quantified based on IOD of fluorescence staining. Data are presented as the mean $\pm \mathrm{SD}$. ${ }^{* *} \mathrm{P}<0.01$. FOXP3, forkhead box P3; MPO, myeloperoxidase; IOD, integrated optical density.
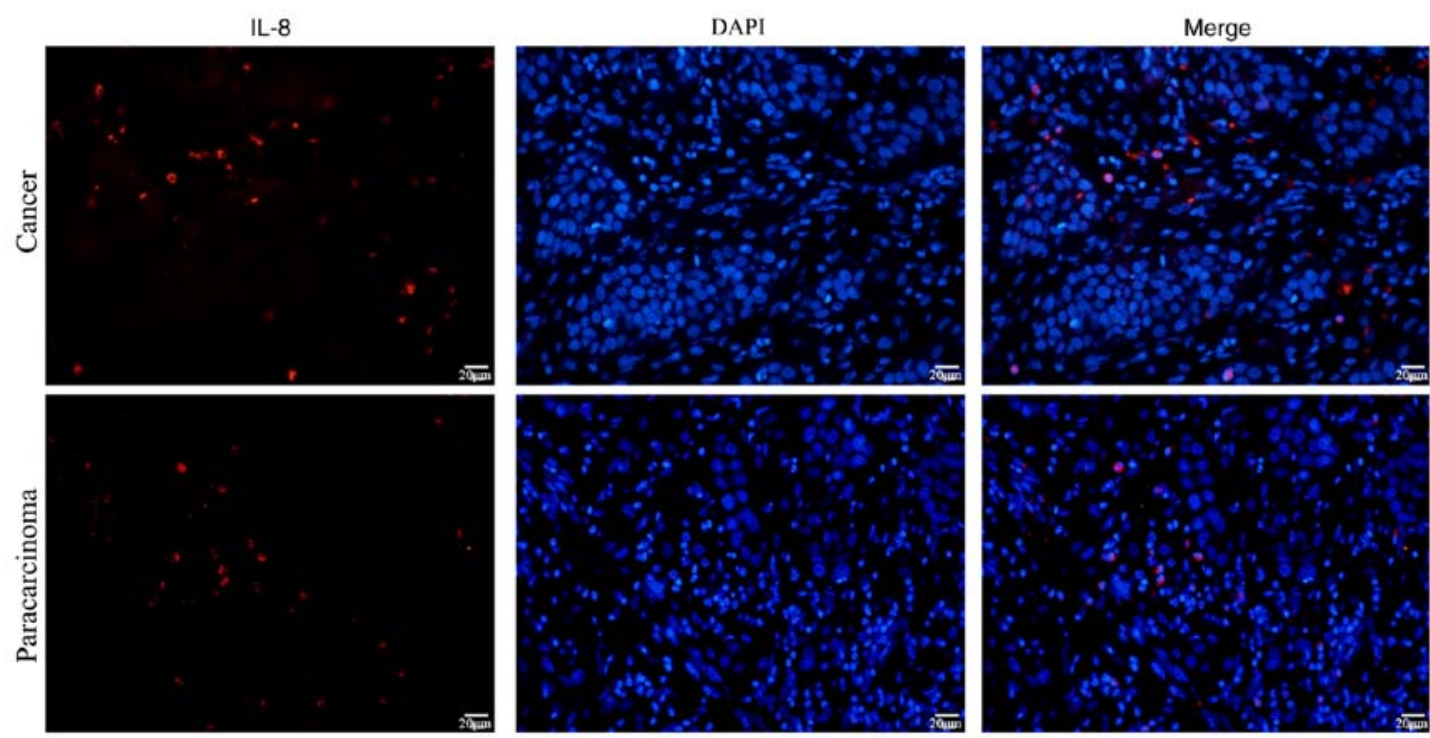

Figure 5. IL-8 protein expression in oral squamous cell carcinoma and paracarcinoma tissue samples. IL-8 protein expression (red) was detected by immunofluorescence. Nuclei (blue) were counterstained with DAPI. Scale bar, $20 \mu \mathrm{m}$. IL-8, interleukin 8. 
does not alter effector $\mathrm{T}$ cell or Treg proliferation in response to stimulation in vitro (24). In the present study, SCC-9 cells were treated with P60 for $24 \mathrm{~h}$, and there was no statistically significant difference identified in the proliferation of SCC-9 cells compared with the control group $(\mathrm{P}=0.656)$. Therefore, P60 alone may not affect the proliferation of SCC- 9 cells. The results revealed that IL-8 downregulated FOXP3 expression in neutrophils, but its specific signaling pathway was not examined in the present study. According to other studies, IL-6 and IL-27 inhibit FOXP3 expression by activating the STAT3 signaling pathway $(39,40)$. Furthermore, a study by $\mathrm{Qu}$ et al $(41)$ revealed that IL-8 increased STAT3 phosphorylation, whereas knockout of IL-8 reduced phosphorylation of STAT3, suggesting that IL-8 may also suppress FOXP3 expression in neutrophils by activating the STAT3 signaling pathway.

TANs serve an important role in the progression of tumor development. For example, neutrophil-released neutrophil elastase (NE) causes a release of growth factors, thereby promoting tumor cell proliferation (6). NE also promotes tumor cell proliferation by degrading insulin receptor substrate 1 (42). In addition, in the tumor microenvironment, neutrophils promote the proliferation of tumor cells by releasing neutrophil extracellular traps (NETs) into the microenvironment $(43,44)$. The present study revealed that IL-8 downregulated FOXP3 expression in neutrophils, and IL-8 treatment combined with co-culturing with neutrophils promoted the proliferation of SCC-9 cells. In addition, the present study demonstrated that the expression of FOXP3 in neutrophils in samples from patients with stage IV tumors was lower compared with that in stage III and II patients. This suggested that downregulation of FOXP3 in neutrophils in the cancer microenvironment may be associated with progression of OSCC. Chung et al (45) demonstrated that in Foxp3-deficient mice, the microglia produced increased quantities of reactive oxygen species (ROS) when treated with lipopolysaccharide compared with the wild-type mice. FOXP3 negatively regulated the production of ROS by activating $\mathrm{NF}-\kappa \mathrm{B}(45)$. A previous study on NETs suggested that increased levels of ROS in neutrophils can promote the formation and release of NETs (46). Considering the results of these previous studies, it was hypothesized that IL-8 recruited neutrophils from the blood vessel to the local tumor microenvironment and downregulated $F O X P 3$ expression in neutrophils. The downregulation of FOXP3 expression in neutrophils may subsequently lead to increased production of ROS in neutrophils, and potentially promote the production and release of NETs, stimulating the proliferation of OSCC cells.

In summary, IL-8 in the tumor microenvironment may recruit neutrophils, and downregulation of FOXP3 in neutrophils by IL-8 may promote the progression of OSCC. These finding expands the range of known mechanisms through which neutrophils promote proliferation of tumor cells and thus, tumor progression. However, additional studies are required to fully elucidate the underlying mechanisms.

\section{Acknowledgements}

The authors would like to thank the pathologists, Professor Haiyun Qing and Professor Yiping Yang (College of Stomatology, Guangxi Medical University) for their assistance in pathological diagnosis.

\section{Funding}

The present study was supported by grants from the National Natural Science Foundation of China (grant no. 81360403) and the Medical and Health Appropriate Technology Development and Promotion Project of Guangxi (grant no. S2018067).

\section{Availability of data and materials}

The datasets used and/or analyzed during the present study are available from the corresponding author on reasonable request.

\section{Authors' contributions}

FL and HK conceived the study and participated in its design. $\mathrm{CZ}$ and FL drafted the manuscript. CZ, XC and WF performed the cell experiments. QT, ZZ and TY performed sample collection and immunofluorescence staining. All authors read and approved the final manuscript.

\section{Ethics approval and consent to participate}

The present study was approved by the Ethics Committee of Guangxi Medical University. Written informed consent was provided by all patients and healthy volunteers.

\section{Patient consent for publication}

Not applicable.

\section{Competing interests}

The authors declare that they have no competing interests.

\section{References}

1. Torre LA, Bray F, Siegel RL, Ferlay J, Lortet-Tieulent J and Jemal A: Global cancer statistics, 2012. CA Cancer J Clin 65: 87-108, 2015.

2. Nasry WHS, Rodriguez-Lecompte JC and Martin CK: Role of COX-2/PGE2 mediated inflammation in oral squamous cell carcinoma. Cancers (Basel) 10: E348, 2018.

3. Haqqani AS, Sandhu JK and Birnboim HC: Expression of interleukin-8 promotes neutrophil infiltration and genetic instability in mutatect tumors. Neoplasia 2: 561-568, 2000.

4. Lalla RV, Spiro JD, Tanzer ML and Kreutzer DL: Association of fibrin and interleukin 8 in human oral squamous cell carcinoma. Oral Surg Oral Med Oral Pathol Oral Radiol Endod 95: 452-457, 2003.

5. Bekes EM, Schweighofer B, Kupriyanova TA, Zajac E, Ardi VC, Quigley JP and Deryugina EI: Tumor-recruited neutrophils and neutrophil TIMP-free MMP-9 regulate coordinately the levels of tumor angiogenesis and efficiency of malignant cell intravasation. Am J Pathol 179: 1455-1470, 2011.

6. Wada Y, Yoshida K, Tsutani Y, Shigematsu H, Oeda M, Sanada Y, Suzuki T, Mizuiri H, Hamai Y, Tanabe K, et al: Neutrophil elastase induces cell proliferation and migration by the release of TGF-alpha, PDGF and VEGF in esophageal cell lines. Oncol Rep 17: 161-167, 2007.

7. Bennett CL, Christie J, Ramsdell F, Brunkow ME, Ferguson PJ, Whitesell L, Kelly TE, Saulsbury FT, Chance PF and Ochs HD: The immune dysregulation, polyendocrinopathy, enteropathy, $\mathrm{X}$-linked syndrome (IPEX) is caused by mutations of FOXP3. Nat Genet 27: 20-21, 2001.

8. Hori S, Nomura T and Sakaguchi S: Control of regulatory T cell development by the transcription factor Foxp3. Science 299: 1057-1061, 2003 
9. Jia H, Qi H, Gong Z, Yang S, Ren J, Liu Y, Li MY and Chen GG: The expression of FOXP3 and its role in human cancers. Biochim Biophys Acta Rev Cancer 1871: 170-178, 2019.

10. Wolf D, Wolf AM, Rumpold H, Fiegl H, Zeimet AG, Muller-Holzner E, Deibl M, Gastl G, Gunsilius E and Marth C: The expression of the regulatory $\mathrm{T}$ cell-specific forkhead box transcription factor FoxP3 is associated with poor prognosis in ovarian cancer. Clin Cancer Res 11: 8326-8331, 2005.

11. Hinz S, Pagerols-Raluy L, Oberg HH, Ammerpohl O, Grüssel S, Sipos B, Grützmann R, Pilarsky C, Ungefroren H, Saeger HD, et al: Foxp3 expression in pancreatic carcinoma cells as a novel mechanism of immune evasion in cancer. Cancer Res 67: 8344-8350, 2007.

12. Liu R, Liu C, Chen D, Yang WH, Liu X, Liu CG, Dugas CM, Tang F, Zheng P, Liu Y and Wang L: FOXP3 controls an miR-146/NF- $\kappa \mathrm{B}$ negative feedback loop that inhibits apoptosis in breast cancer cells. Cancer Res 75: 1703-1713, 2015.

13. Zhang HY and Sun H: Up-regulation of Foxp3 inhibits cell proliferation, migration and invasion in epithelial ovarian cancer. Cancer Lett 287: 91-97, 2010.

14. Trellakis S, Bruderek K, Dumitru CA, Gholaman H, Gu X, Bankfalvi A, Scherag A, Hütte J, Dominas N, Lehnerdt GF, et al: Polymorphonuclear granulocytes in human head and neck cancer: Enhanced inflammatory activity, modulation by cancer cells and expansion in advanced disease. Int J Cancer 129: 2183-2193, 2011

15. Wang N, Feng Y, Wang Q, Liu S, Xiang L, Sun M, Zhang X, Liu G, Qu X and Wei F: Neutrophils infiltration in the tongue squamous cell carcinoma and its correlation with CEACAM1 expression on tumor cells. PloS One 9: e89991, 2014.

16. Fridlender ZG, Sun J, Kim S, Kapoor V, Cheng G, Ling L, Worthen GS and Albelda SM: Polarization of tumor-associated neutrophil phenotype by TGF-beta: 'N1' versus 'N2' TAN. Cancer Cell 16: 183-194, 2009.

17. Piccard H, Muschel RJ and Opdenakker G: On the dual roles and polarized phenotypes of neutrophils in tumor development and progression. Crit Rev Oncol Hematol 82: 296-309, 2012.

18. Nozawa $\mathrm{H}$, Chiu $\mathrm{C}$ and Hanahan D: Infiltrating neutrophils mediate the initial angiogenic switch in a mouse model of multistage carcinogenesis. Proc Natl Acad Sci USA 103: 12493-12498, 2006.

19. Tateda K, Moore TA, Newstead MW, Tsai WC, Zeng X, Deng JC, Chen G, Reddy R, Yamaguchi K and Standiford TJ: Chemokine-dependent neutrophil recruitment in a murine model of legionella pneumonia: Potential role of neutrophils as immunoregulatory cells. Infect Immun 69: 2017-2024, 2001.

20. Sobin LH, Gospodarowicz MK and Wittekind C: TNM Classification of malignant tumours (UICC International Union Against Cancer). 7th edition. Wiley-Blackwell, Oxford, 2009.

21. Bancroft $\mathbf{J}$ and Stevens A: Theories and practice of histological techniques. Churchill Livingstone, New York, USA, pp 124-150, 1996.

22. Capes-Davis A, Reid YA, Kline MC, Storts DR, Strauss E, Dirks WG, Drexler HG, MacLeod RA, Sykes G, Kohara A, et al: Match criteria for human cell line authentication: Where do we draw the line? Int J Cancer 132: 2510-2519, 2013

23. Grandel U, Heygster D, Sibelius U, Fink L, Sigel S, Seeger W, Grimminger $\mathrm{F}$ and Hattar K: Amplification of lipopolysaccharide-induced cytokine synthesis in non-small cell lung cancer/neutrophil cocultures. Mol Cancer Res 7: 1729-1735, 2009.

24. Casares N, Rudilla F, Arribillaga L, Llopiz D, Riezu-Boj JI, Lozano T, Lopez-Sagaseta J, Guembe L, Sarobe P, Prieto J, et al: A peptide inhibitor of FOXP3 impairs regulatory T cell activity and improves vaccine efficacy in mice. J Immunol 185: 5150-5159, 2010

25. Fecci PE, Mitchell DA, Whitesides JF, Xie W, Friedman AH, Archer GE, Herndon JE II, Bigner DD, Dranoff G and Sampson JH Increased regulatory $\mathrm{T}$-cell fraction amidst a diminished CD4 compartment explains cellular immune defects in patients with malignant glioma. Cancer Res 66: 3294-3302, 2006.

26. Winer J, Jung CK, Shackel I and Williams PM: Development and validation of real-time quantitative reverse transcriptase-polymerase chain reaction for monitoring gene expression in cardiac myocytes in vitro. Anal Biochem 270: 41-49, 1999.

27. Schmittgen TD, Zakrajsek BA, Mills AG, Gorn V, Singer MJ and Reed MW: Quantitative reverse transcription-polymerase chain reaction to study mRNA decay: Comparison of endpoint and real-time methods. Anal Biochem 285: 194-204, 2000.

28. McDonald RJ, St George JA, Pan LC and Hyde DM: Neutrophil adherence to airway epithelium is reduced by antibodies to the leukocyte CD11/CD18 complex. Inflammation 17: 145-151, 1993.
29. Crowe SE, Alvarez L, Dytoc M, Hunt RH, Muller M, Sherman P, Patel J, Jin Y and Ernst PB: Expression of interleukin 8 and CD54 by human gastric epithelium after Helicobacter pylori infection in vitro. Gastroenterology 108: 65-74, 1995.

30. Mole DJ, Webster SP, Uings I, Zheng X, Binnie M, Wilson K, Hutchinson JP, Mirguet O, Walker A, Beaufils B, et al: Kynurenine-3-monooxygenase inhibition prevents multiple organ failure in rodent models of acute pancreatitis. Nat Med 22: 202-209, 2016

31. Chen CB, Liu LS, Zhou J, Wang XP, Han M, Jiao XY, He XS and Yuan XP: Up-regulation of HMGB1 exacerbates renal ischemia-reperfusion injury by stimulating inflammatory and immune responses through the TLR4 signaling pathway in mice. Cell Physiol Biochem 41: 2447-2460, 2017.

32. Zuo T, Wang L, Morrison C, Chang X, Zhang H, Li W, Liu Y, Wang Y, Liu X, Chan MW, et al: FOXP3 is an X-linked breast cancer suppressor gene and an important repressor of the HER-2/ErbB2 oncogene. Cell 129: 1275-1286, 2007.

33. Fujita Y, Okamoto M, Goda H, Tano T, Nakashiro K, Sugita A, Fujita T, Koido S, Homma S, Kawakami Y and Hamakawa H: Prognostic significance of interleukin-8 and CD163-positive cell-infiltration in tumor tissues in patients with oral squamous cell carcinoma. PLoS One 9: e110378, 2014

34. Sun X, Feng Z, Wang Y, Qu Y and Gai Y: Expression of Foxp3 and its prognostic significance in colorectal cancer. Int J Immunopathol Pharmacol 30: 201-206, 2017.

35. Shi JY, Ma LJ, Zhang JW, Duan M, Ding ZB, Yang LX, Cao Y, Zhou J, Fan J, Zhang X, et al: FOXP3 Is a HCC suppressor gene and Acts through regulating the TGF- $\beta / \mathrm{Smad} 2 / 3$ signaling pathway. BMC Cancer 17: 648, 2017.

36. Yang S, Liu Y, Li MY, Ng CSH, Yang SL, Wang S, Zou C, Dong Y, Du J, Long X, et al: FOXP3 promotes tumor growth and metastasis by activating Wnt $/ \beta$-catenin signaling pathway and EMT in non-small cell lung cancer. Mol Cancer 16: 124, 2017.

37. Zhang C, Xu Y, Hao Q, Wang S, Li H, Li J, Gao Y, Li M, Li W, Xue X, et al: FOXP3 suppresses breast cancer metastasis through downregulation of CD44. Int J Cancer 137: 1279-1290, 2015.

38. Liu R, Liu C, Chen D, Yang WH, Liu X, Liu CG, Dugas CM, Tang F, Zheng P, Liu Y and Wang L: FOXP3 Controls an miR-146/NF- $\kappa \mathrm{B}$ negative feedback loop that inhibits apoptosis in breast cancer cells. Cancer Res 75: 1703-1713, 2015.

39. Yao Z, Kanno Y, Kerenyi M, Stephens G, Durant L, Watford WT, Laurence A, Robinson GW, Shevach EM, Moriggl R, et al: Nonredundant roles for $S t a t 5 \mathrm{a} / \mathrm{b}$ in directly regulating Foxp3. Blood 109: 4368-4375, 2007

40. Huber M, Steinwald V, Guralnik A, Brüstle A, Kleemann P, Rosenplänter C, Decker T and Lohoff M: IL-27 inhibits the development of regulatory T cells via STAT3. Int Immunol 20: 223-234, 2008

41. Qu JQ, Yi HM, Ye X, Li LN, Zhu JF, Xiao T, Yuan L, Li JY, Wang YY, Feng J, et al: MiR-23a sensitizes nasopharyngeal carcinoma to irradiation by targeting IL-8/Stat 3 pathway. Oncotarget 6: 28341-28356, 2015.

42. Houghton AM, Rzymkiewicz DM, Ji H, Gregory AD, Egea EE, Metz HE, Stolz DB, Land SR, Marconcini LA, Kliment CR, et al: Neutrophil elastase-mediated degradation of IRS-1 accelerates lung tumor growth. Nat Med 16: 219-223, 2010.

43. Cools-Lartigue J, Spicer J, Najmeh S and Ferri L: Neutrophil extracellular traps in cancer progression. Cell Mol Life Sci 71: 4179-4194, 2014.

44. Tohme S, Yazdani HO, Al-Khafaji AB, Chidi AP, Loughran P, Mowen K, Wang Y, Simmons RL, Huang H and Tsung A: Neutrophil extracellular traps promote the development and progression of liver metastases after surgical stress. Cancer Res 76: 1367-1380, 2016.

45. Chung HS, Lee JH, Kim H, Lee HJ, Kim SH, Kwon HK, Im SH and Bae H: Foxp3 is a novel repressor of microglia activation. Glia 58: 1247-1256, 2010.

46. Lood C, Blanco LP, Purmalek MM, Carmona-Rivera C, De Ravin SS, Smith CK, Malech HL, Ledbetter JA, Elkon KB and Kaplan MJ: Neutrophil extracellular traps enriched in oxidized mitochondrial DNA are interferogenic and contribute to lupus-like disease. Nat Med 22: 146-153, 2016.

This work is licensed under a Creative Commons Attribution-NonCommercial-NoDerivatives 4.0 International (CC BY-NC-ND 4.0) License. 